\title{
The Model Development of Frisbee Game as an Alternative Learning of Physical Education Sport and Health of Senior High School Students
}

\author{
Alief Dedi Kenedi ${ }^{1}$, Soegiyanto ${ }^{2}$, Sulaiman $^{3}$ \\ ${ }^{1}$.SMA Negeri 1 Cirebon, Indonesia. \\ 2.,3 Universitas Negeri Semarang, Indonesia \\ Corresponding email: dedi.kenedi@gmail.com
}

\begin{abstract}
The problem of this research is Frisbee game model as a sport that introduced and practiced in learning activity needs to be developed as an alternative learning. The aim of this research is to know the model product of using frisbee game as an alternative learning and to produce the a cceptance of Frisbee game's product. The research is Reasearch and Development (R\&D) of Frisbee game model as an alternative learning. The Population and sample in this research is students of SMA Negeri 1 Cirebon at the rate of 864 students from taking the sample of all grade students with 288 respondents. Technique of analyzing the data that is used in this research is precentage analysis. The research finding totally shows that research between student's motivation and the effectiveness acceptance of this Frisbee game is about 83,36\% that includes aspects of Psychomotor, Cognitive, Affective, Infrastructure and Physical aspects of $83.36 \%$, which means a very positive acceptance. The research can be concluded that 1) the development of Frisbee game model gave a new alternative for being applied in teaching. 2) the Frisbee game rules, field modifications of Firsbee, 2 rings in one pole model, number of players and frisbee rubber or other material can be delivered learning.
\end{abstract}

Keywords: Development, Frisbee Game and Learning Alternative

\section{Introduction}

The physical education learning process in schools one of them is to introduce basic movements in a complex way so that students are able to carry out sports forms through media or game tools.

Penjasorkes is unique and needs to be dealt with the rules of sport appropriately and proportionally. Kartadinata (2011) states that there are three important things as unique contributions from Penjasorkes, (1) improving physical fitness and students' health, (2) improving the mastery of rich physical skills, (3) improving students' understanding of the principles of motion and how to apply it in practice.

Chatib (2012) stated there are 3 major forces in learning, namely (1) paradigm, (2) ways, and (3) commitment of these three domains as content in learning. Physical education learning will be systematically carried out by the teacher if the learning begins with a mature and structured learning plan and can be developed. Martiyono (2012) states the learning plan can be developed by anyone who has the competence to develop a learning plan, in formal learning at school educators as a subsystem of the learning process have a task, responsibility for planning learning.

The development of the Frisbee game model as an alternative to Physical Education learning for students of SMA Negeri 1 Cirebon is expected to contribute to the innovative learning tools in the learning activitiy process. The product produced in the development research is a Frisbee game model as an alternative to the physical education learning program for class X SMA Negeri 1 Cirebon for effectiveness, motivating, increasing knowledge and skills in the learning process of Penjasorkes movement, which has specifications. Abdurrahman (2012) Strategies for motor development must include (1) throwing, (2) catching, (3) playing football, (4) playing inner tubes, (5) playing balls from cloth, (6) eye and hand coordination activities, (7) tracing, (8) cutting, (9) sticking, and (10) folding.

\section{Methods}

The research method used is the Research and Development / R \& D method. Furthermore, it is stated that the research and development procedure basically has two main objectives: 1) developing products, and 2) testing the effectiveness of the product in achieving its objectives. (Wasis: 2010)

Based on some of these opinions, the procedure used in the development of a frisbee game model for physical education of high school students uses strategic and effective steps which include product development 
planning to be developed, 1) The survey of Frisbee games in schools (students and Physical Education teacher) and community, 2) General frisbee assessment and characteristics of frisbee play, 3) Determine the form of frisbee games from field infrastructure (size, goal), tools used (appropriate frisbee), rules of the game to be played in learning frisbee.

Developing the initial product of frisbee game for 10th grade students of SMA Negeri 1 Cirebon, which are, 1) Analysis of the objectives and the product character that will be developed, 2) Analysis of the character of 10th grade students of SMA Negeri 1 Cirebon, 3 ) designing the desired objectives in order for the students to be able to do their roles in the lesson, 4) Designing the form of frisbee game in Physical Education lesson as an alternative sport for learning material in Physical Education at school with the available frisbee in considerations and comparisons adjusted to the situation and condition of the school, 5) Developing and increasing the physical fitness contained in frisbee game as the alternative of learning material for Physical Education at school, 6) Measuring the students' learning outcome as a part of the learning process of frisbee game as the sport alternative in the material of the Physical Education lesson, 7) Making a field design with flexible size in the learning process in accordance of the school's infrastructure that will be studied gradually in order to get a valid result of the field's size.

Expert validation, in order to validate the product that will be produced, the researcher involved 2 (two) experts who came from lecturers and 3 (three) high school Physical Education teachers. Field trial. Field trial was conducted to obtain product responses and revisions, and to produce the final product in the form of developing a suitable frisbee game model. The trial was carried out by testing small class groups and field trials.

Product Revision. The revision of frisbee game model products is done to improve the product for the better. Product Trial. The trial was conducted to obtain some information for the benefit of revising the product. This trial involved several subjects, namely: 1) learning experts, 2) teachers in the Physical Education study program, 3) frisbee game experts, 4) small class group trials and 5) field trials. The data used are qualitative data, namely from the results of interviews, observations, advice from experts, sports teachers and resource persons both orally and in writing, and quantitatively as material for product revisions while quantitative data is obtained from pulse taking, frisbee throwing, usage facilities and quality models of students through questionnaires distributed to all respondents. The study population was the students of SMA Negeri 1 Cirebon class of 2011, 2013 while the research sample was students of Class X of SMA Negeri 1 Cirebon class of 2012/2013 with the total of 288 students.

\section{Results and Discussions}

Based on the results of the data analysis it can be concluded that according to the distribution, the motivation response in learning and the effectiveness of the acceptance of the development of the frisbee game model as an alternative learning for students of SMA Negeri 1 Cirebon can motivate the students' positive response in learning Physical Education by $82.67 \%$, while the negative response is $17.33 \%$. The category of acceptability of the positive response for students in the frisbee game model is $84.06 \%$ while the negative response is $15.94 \%$, so the conclusions of the two categories of motivation responses to physical education learning and acceptability of responses to frisbee games fall into a very good category. The overall data from respondents states that there is a positive response to students that is analyzed by percentage and it shows that $83.36 \%$ of students gave a positive response and $16.64 \%$ gave a negative response, meaning that more than $75 \%$ students gave a positive response, so it can be categorized that the students' acceptance responses are very positive and the mark of 28810 are included in the interval category "good and very good" but it is more likely to be considered as very well.

The Frisbee Game Model as an Alternative can Motivate Students to Learn Physical Education. The lesson that is based on the ability of motion carried out by students is a description of the final result of a positive response that motivates students in learning Physical Education amounting to $82.67 \%$. The results of the category of acceptability effectiveness of the students' positive response to the frisbee game are $84.06 \%$, the acceptance of the response to the frisbee game included in the category is very good and the percentage exceeded $75 \%$. The overall result of the process towards the development of the frisbee game 
model as an alternative to physical education learning is $83.36 \%$, while the physical aspect of the increase in the pulse of the exercise for male students is $30.33 \%$ and $27.05 \%$ for female so that it is included in the classification category "well" in increasing the pulse of the exercise

\section{Conclusions}

Based on the analysis of the results of the study and the discussion in this thesis, a conclusion can be drawn as follows: 1) the resulting frisbee game model which was introduced and delivered as an alternative Physical Education learning in schools can provide positive motivation for students by $82.67 \%$. 2) The effectiveness of Frisbee game model products can be accepted by students for improving cognitive, psychomotor, and affective aspects by $84.06 \%$. Overall the study between student motivation and effectiveness of Frisbee game model products was $83.36 \%$, which means that the acceptance was very positive, while the physical aspect of the increase in exercise pulse for male students was $30.33 \%$ and the female was $27.05 \%$ so that it was included in the category classification both in increasing the pulse of the exercise. 3) Frisbee game models can be applied in schools by producing rules for Frisbee games, Frisbee field modifications, 2 Frisbee goal ring models in 1 pole, number of players and Frisbee material made of rubber.

\section{References}

Abdurrrahman, Mulyono. 2012. Anak Berkesesulitan Belajar Teori, Diagnosan dan Remediasinya. Jakarta: PT. Rineka Cipta.

Chotib, Munif, 2012. Gurunya Manusia. Bandung: Kaifa PT. Mizan Pustaka.

Kartadinata. 2011. Pendidikan dan Latihan Profesi Guru (PLPG) Rayon 110.2011. Bahan Ajar Pendidikan Jasmani. Bandung: Universitas Pendidikan Indonesia

Martiyono. 2012. Perencanaan Pembelajaran. Yogyakarta: Aswaja Pressindo.

Wasis. 2010. Penelitian Keolahragaan. Malang: Universitas Negeri Malang (UM PRESS). 